\title{
Non-Invasive Intracranial Pulse Wave Monitoring *
}

\author{
Arminas RAGAUSKAS, Gediminas DAUBARIS, Vytautas PETKUS, \\ Romanas CHOMSKIS, Renaldas RAISUTIS, Vytautas DEKSNYS, \\ Jonas GUZAITIS, Gintautas LENGVINAS, Vaidas MATIJOSAITIS \\ $U A B$ Vittamed technologijos \\ V. Putvinskio 47-10, Kaunas LT-44243, Lithuania \\ e-mail:info@vittamedtechnologijos.lt
}

Received: 5 February 2008; accepted: 23 April 2008

\begin{abstract}
Non-invasive physiological monitors are important subsystems of intensive care informatic systems. New innovative information methods and technology are presented for non-invasive human brain volumetric pulse wave physiological monitoring.

Experimental study of a new, non-invasive ultrasonic intracranial pulse wave monitoring technology show the reactions of non-invasively recorded intracranial blood volume pulse waves (IBVPW) on healthy volunteers in different human body positions. A group of 13 healthy volunteers was studied.

Body posture caused IBVPW, subwaves changes, $\triangle \mathrm{P} 2=18 \%$ and $\Delta \mathrm{P} 3=11 \%$. The value of the IBVPW amplitude's ratio in supine and upright positions was $1.55 \pm 0.61$.
\end{abstract}

Keywords: information technology, body posture, intracranial pressure, intracranial blood volume pulse waves, cerebral hemodynamics, non-invasive monitoring, time-frequency filtering.

\section{Introduction}

Body posture strongly affects intracranial hydrodynamics and cerebral hemodynamics. The link between posture-related changes in cerebral hemodynamics, intracranial hydrodynamics and patterns of venous drainage can be quantified by cine phase-contrast magnetic resonance imaging (MRI) (Raksin et al., 2003; Alperin et al., 2005). The ability to non-invasively quantify the effect of posture on intracranial physiology may lead to the development of new diagnostic tests to evaluate functions such as regulation of CBF and ICP and the effect of pathologies on these functions. It has been shown that, in the posture changes of healthy volunteers from supine to upright positions, the intracraniospinal compliance changes up to 2.8 times when ICP changes from $10.6 \pm 3.6 \mathrm{mmHg}$ to $4.5 \pm 1.82 \mathrm{mmHg}$ (Alperin et al., 2005). The study (Alperin et al., 2005) showed that posture-related changes in ICC and ICP have a great impact on cerebral blood as well as on CSF circulation. It has also been shown in the original MRI study that the shape of IBV pulse waves is strongly related to intracraniospinal compliance (Alperin et al., 2005).

\footnotetext{
*This research was supported by UAB "Vittamed technologijos" and EU Structural Funds Project "Technological development and applied research of complex equipment and innovative non-invasive methods of human brain physiological monitoring” BPD04-ERPF-3.1.7-03-05/0020
} 
The study found that results can be obtained which are similar to MRI technology by using the non-invasive ultrasonic method for intracranial blood volume pulse wave (IBVPW) measurement (Ragauskas and Daubaris, 1995; Ragauskas et al., 1999-2004; Deltuva, 1999; Matukevicius, 2000; Rocka, 2003; Ragaisis, 2003; Kvascevicius, 2003; Kalasauskas, 2003; Chambers et al., 2005; Fountas et al., 2005). The method has been tested using simultaneous invasive ICP and non-invasive IBV wave monitoring of TBI patients. A study on animals has also been performed, and the body posture effect on ICP and IBV pulse wave shape has been investigated (Ragauskas and Kanapienis, 1999). There were 13 patients with TBI monitored following Clinical Research Protocol No. 99124006, AIBS No. 990135, HSSRB log No. A-9676. The analysis involved 87 hours of simultaneous monitoring of invasive and non-invasive data (Ragaisis, 2003; Chambers et al., 2005). The diagnostic value of IBV pulse waves has been investigated in previous studies (Ragauskas et al., 1999-2004; Rocka, 2003; Kvascevicius, 2003; Kalasauskas, 2003; Fountas et al., 2005).

A total of 75 patients were examined using ultrasonic non-invasive method and they included cases of acute, chronic and stabilized hydrocephalus, spinal cord injury and terminal blood flow (Rocka, 2003; Kvascevicius, 2003; Chambers et al., 2005). They were compared to a control group of 53 healthy volunteers. A detectable change in IBV pulse waveform shape was observed in situations when there was a disturbance in intracranial hydrodynamics, e.g. during hypoventilation tests, in cases of terminal blood flow and hydrocephaly depicting the level of hydrocephalus activity and a patient's compensatory capabilities as well as the effect of treatment (Rocka, 2003; Kvascevicius, 2003; Chambers et al., 2005).

The objective of the study was to develop innovative methods and design equipment for non-invasive ultrasonic measurement of intracranial volumetric pulse waves. Furthermore, another objective of the present study was to investigate, for the first time, the changes in the IBV pulse wave shape of healthy volunteers in supine and upright body positions and investigate IBV pulse wave parameter changes caused by the breath holding test. The new, ultrasonic Vittamed 105 pulse wave monitor has been used for these purposes.

\section{Materials and Methods}

The available brain physiological monitoring technologies are exceedingly invasive.

A non-invasive method of intracranial blood volume measurement using ultrasound is based on the transmission of short ultrasonic pulses from one side of the skull to the other and dynamic measurements of the time-of-flight of ultrasonic pulses. The time-of-flight depends on the acoustic properties of intracranial blood, brain tissue and cerebrospinal fluid. Changes in the volume of any of these components will change the time-of-flight (Ragauskas et al., 2003). 


\section{Computer Simulation}

The idea of measuring the changes of intracranial component volumes non-invasively is based on the transmission of a broadband ultrasonic signal through the human head and monitoring such signal parameters as the time-of-flight and the oscillation period (Ragauskas and Daubaris, 1995; Ragauskas et al., 1999, 2002). As all intracranial components (brain tissue, cerebrospinal fluid, blood) have different acoustic properties (ultrasound speed, frequency dependent attenuation), changes of their content inside the acoustic path will influence the total acoustic characteristics of IM and the monitored parameters of the ultrasonic signal as well.

While developing a model of the human cranium as a model of the acoustic media it was assumed that the total head volume is $1300 \mathrm{ml}$ consisting of $1150 \mathrm{ml}(88.46 \%)$ of brain tissue, $75 \mathrm{ml}$ (10\%) of cerebrospinal fluid (CSF), and $75 \mathrm{ml}(10 \%)$ of blood (Thoman, 1997). The assumption was made that the ultrasonic signal propagates through the cranium $15 \mathrm{~cm}$ on a straight line and the thickness of cranial components (according to the proportions presented above) are $13.27 \mathrm{~cm}$ of brain tissue, $0.865 \mathrm{~cm}$ of CSF and $0.865 \mathrm{~cm}$ of blood, respectively. For evaluating the influence of the skull bone, the thickness of bone layers on each side of the head was assumed to be equal to $0.8 \mathrm{~cm}$. The acoustic parameters of the media components were obtained from the references (Hill, 1986; Hynynen and Sun, 1999) and listed in Table 1.

By creating a mathematical model of ultrasound pulse propagation through the human head, it was necessary to take into account the main factors that influence monitored parameters of the ultrasonic signal i.e. ultrasound attenuation, ultrasound velocity dispersion and diffraction effects.

Frequency decomposition method $(\mathrm{He}, 1998)$ was applied for simulating the ultrasound velocity dispersion and ultrasound attenuation effects. The method is based on the decomposition of the broadband ultrasound pulse into narrowband frequency components for which the group delay, phase and attenuation are calculated separately. The relation between the input signal $S_{i n}(t)$ and output signal $S_{i n}(t)$ is defined by the following ex-

Table 1

Media and their acoustic parameters used for simulation

\begin{tabular}{lccc}
\hline \multicolumn{1}{c}{ Medium } & \multicolumn{2}{c}{ Attenuation parameters } & \begin{tabular}{c} 
Ultrasound speed of the \\
longitudinal waves in \\
\cline { 2 - 3 }
\end{tabular} \\
\cline { 2 - 3 } & $\begin{array}{c}\text { Reference attenuation } \\
\text { soefficient, } \alpha_{0}, \\
\mathrm{~dB} /\left(\mathrm{cmMHz}^{n}\right)\end{array}$ & $\begin{array}{c}\text { Power of the } \\
\text { attenuation law, } \\
n\end{array}$ & $n$ \\
\hline Skull bone & 11.089 & 1.89 & 2652 \\
Brain tissue & 0.8692 & 1.078 & 1563 \\
Cerebrospinal fluid & 0.0023 & 1.9937 & 1533 \\
Blood & 0.212 & 1.2662 & 1583 \\
\hline
\end{tabular}


pression:

$$
\begin{aligned}
S_{\text {out }}(t)= & \sum_{i=1}^{m} F T^{-1}\left[S_{\text {in }}(j \omega) \cdot B_{i}(j \omega)\right. \\
& \left.\times \exp \left(-\alpha_{i}(r, \omega)-j \varphi_{i}(r, \omega)-j \omega t_{g i}(r, \omega)\right)\right],
\end{aligned}
$$

where $F T^{-1}$ is the inverse Fourier transformation, $S_{i n}(j \omega)=F T\left(S_{i n}(t)\right)$ is Fourier transformation of the input signal, $\omega=2 \pi f$ is the angular frequency, $\alpha_{i}$, is the ultrasound attenuation, $\varphi_{i}$ is the phase angle, $t_{g i}$ is the group delay, $r$ is the distance of ultrasonic wave propagation (such wave propagates appropriate distance at time delay $\tau$, which depends on ultrasound speed in a medium), $B_{i}(j \omega)$ is the spectrum of decomposition filter, $m$ is the number of filters used for signal decomposition, $i=1, \ldots, m$ are the indices denoting that parameters are calculated at particular frequencies $f_{i}, m$ is a total number of Gaussian filters used in computer simulation. In order to obtain the minimum reconstruction error, the Gaussian filters were chosen for decomposition (He, 1998):

$$
B_{i}(f)=\frac{1}{\pi} \mathrm{e}^{-\left(\frac{f-f_{L}-(i-1) B}{B}\right)^{2}}=\frac{1}{\pi} \mathrm{e}^{-\left(\frac{f-f_{i}}{B}\right)^{2}},
$$

where $f_{i}$ and $B=\left(f_{H}-f_{L}\right) /(m-1)$ are the central frequencies and bandwidth of the filters, $f_{H}, f_{L}$ are the highest and lowest central frequencies of filters, $m$ is the number of filters used for signal decomposition. The bandwidth $B$ is constant for each filters and is chosen narrow enough that the downshift of each decomposed signal component would be negligible (He, 1998) $\left(B=0.15 \mathrm{MHz}, f_{H}=3.6 \mathrm{MHz}\right.$ and $f_{L}=0.3 \mathrm{MHz}$ were used in our simulations).

Coefficients of ultrasound attenuation were obtained from the power law function describing the frequency dependent attenuation in biological tissues (He, 1998):

$$
\alpha_{i}=r \alpha_{0} f_{i}^{n}
$$

where $\alpha_{0}$ and $n$ are the attenuation parameters (reference attenuation coefficient at particular frequency value $f_{0}$ and power of attenuation law) dependent on the tissue (Table 1). These parameters partially condition the phase angle $\left(\phi_{i}\right)$ and the group delay $\left(t_{g i}\right)$ of the propagating signal which according the time causal model (when $n>1$ ) are (Szabo, 1995):

$$
\begin{aligned}
\varphi_{i} & =-(n-1) \omega_{i}^{n} \alpha_{0} r \tan \left(\frac{n \pi}{2}\right) \\
t_{g i} & =\frac{r}{c_{p}\left(\omega_{0}\right)}-\alpha_{0} r \tan \left(\frac{n \pi}{2}\right)\left(n \omega_{i}^{n-1}-\omega_{0}^{n-1}\right) .
\end{aligned}
$$

Here $c_{p}$ is the phase velocity at reference frequency $\omega_{0}$.

The real input ultrasonic signal used for simulation, was copied from the ultrasonic transducers of a non-invasive monitor using PVDF piezofilms and recorded by an oscilloscope HP54615B. The central frequency of ultrasound transducers used for measurement 


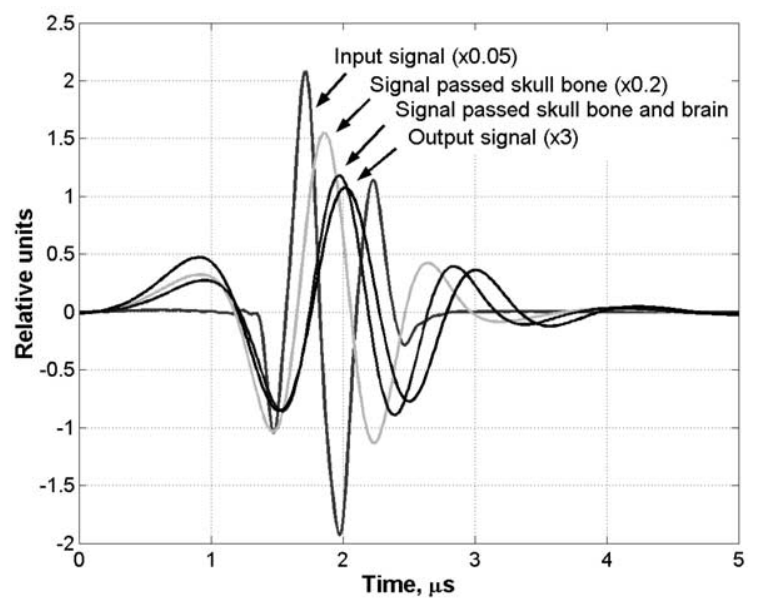

Fig. 1. The change of an ultrasound pulse waveform when it propagates through the human head.

was $f_{0}=1.8 \mathrm{MHz}$. The simulation of this signal propagation through the human head was performed according model presented above. The results of simulation of ultrasound pulse propagation through the human head is shown in Fig. 1.

For comparison, the input signal is multiplied by 0.05 , the signal passed through the skull bone on the one side of the head is multiplied by 0.2 and the signal passed through the whole head is multiplied by 3 . All signals are shifted left in the time domain by their group delays calculated at the frequency $1.8 \mathrm{MHz}\left(t_{\text {group }}(\right.$ bone $)=2.4753 \mu \mathrm{s}$, $t_{\text {group }}($ bone + brain $)=98.8449 \mu \mathrm{s}, t_{\text {group }}($ bone + brain + bone $\left.)=101.8202 \mu \mathrm{s}\right)$.

\section{Experimental Study}

The new Vittamed 105 pulse wave monitor has been created. The algorithm of the pulse wave monitor is presented in Fig. 2.

The pulse wave monitor, has been used to measure and record waveforms at a sampling frequency of $25 \mathrm{~Hz}$. The image of the display panel is presented in Fig. 3. To decrease the influence of heart rate changes and respiratory modulation on the measured waveforms, the measured IBV pulse waves were averaged over at least three respiratory cycles and normalised to the peak value. What we have termed the normalization window in a $1.0 \times 1.0$ dimensionless grid is shown in Fig. 3. It readily allows a comparison of different IBV pulse wave recordings.

A group of 13 healthy volunteers $(9 \mathrm{~F}, 4 \mathrm{M}$, mean age $25.1 \pm 3.4)$ were studied in supine and upright body positions. Each volunteer performed the breath holding test for $30 \mathrm{sec}$ in a supine body position. Neither of them had any history of headaches, neuroinfections, head trauma, neurosurgical operations or any other symptoms of elevated ICP. The volunteers were investigated with a 3-minute data recording test following the protocol of beginning in an upright (standing) position. 


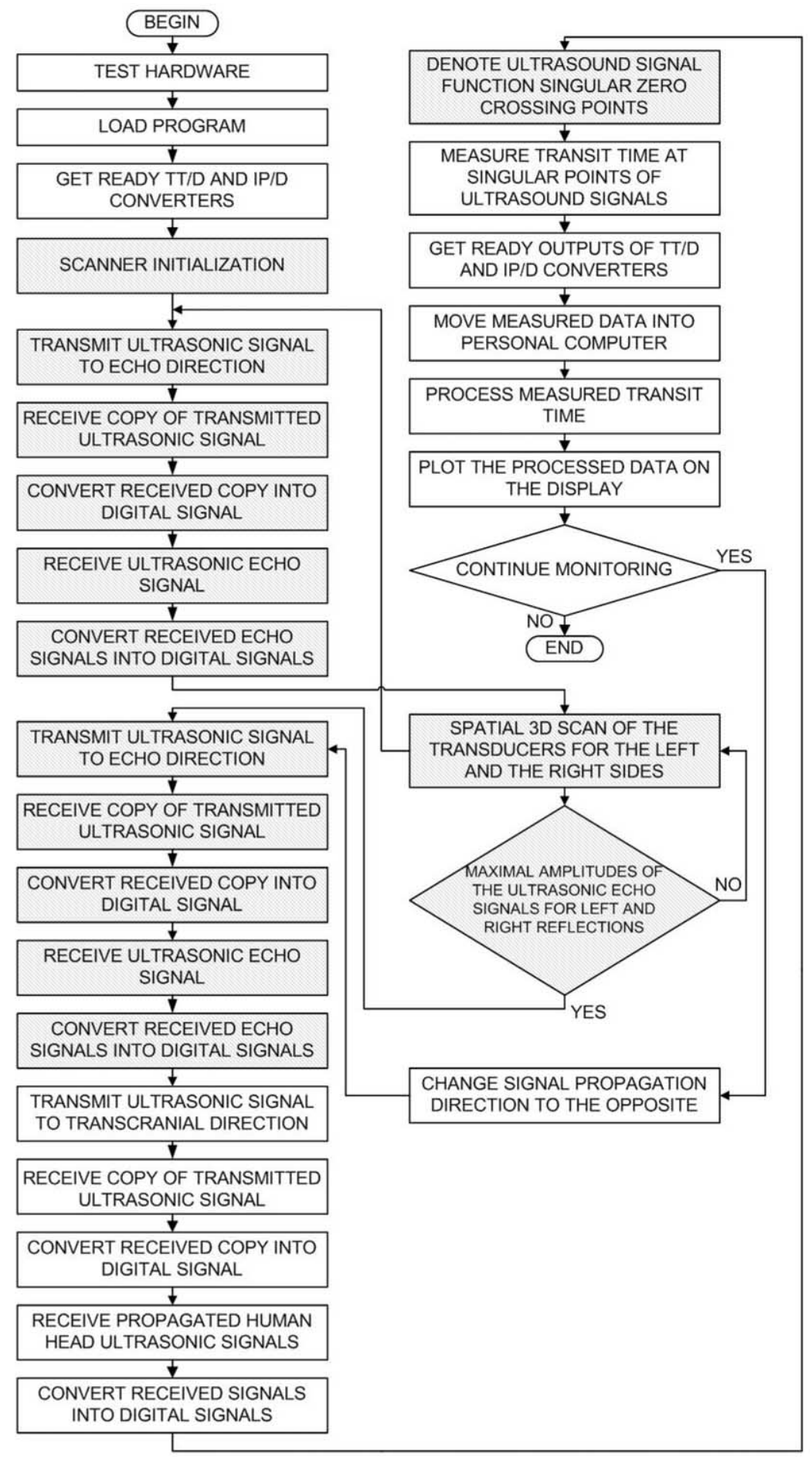

Fig. 2. The hardware managing algorithm of the pulse wave monitor. 


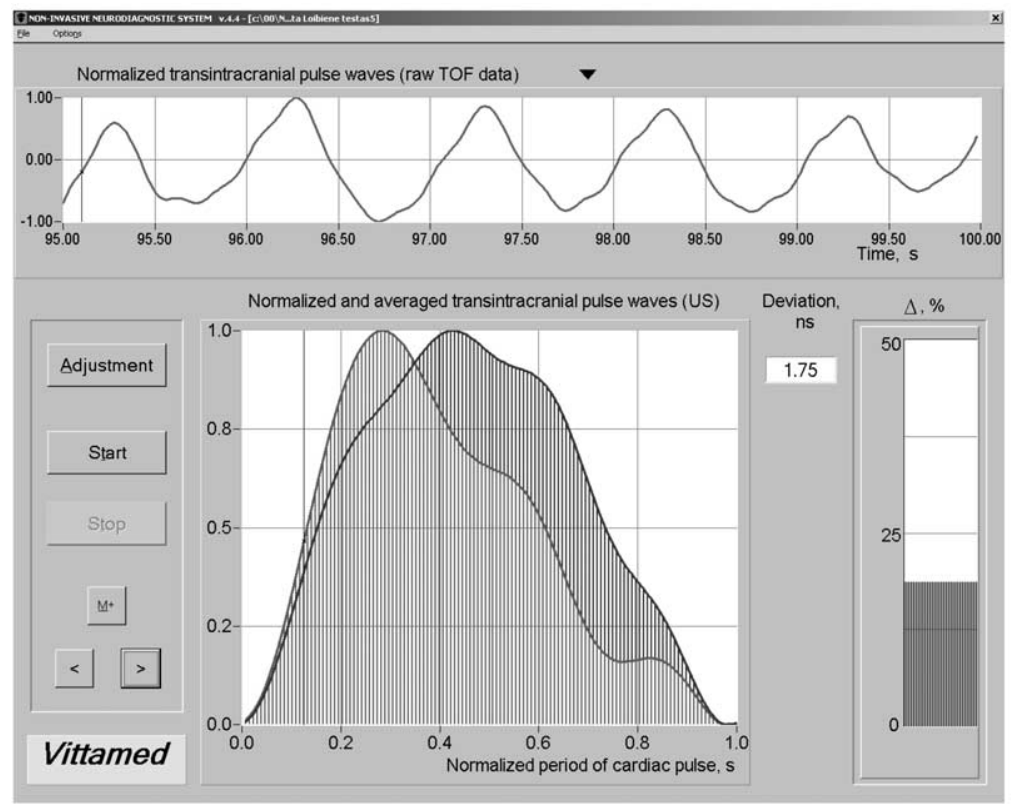

Fig. 3. The display panel of the non-invasive monitor for intracranial blood volume pulse wave shape comparison - two IBV pulse waves are shown in the normalised window with dimensions of $1.0 \times 1.0$ reference (left) wave in an upright body position and the (right) wave under comparison in a supine body posture when ICP has been elevated.

A 3-minute resting time interval was used after taking data in a supine body position. After that a 3-minutes recording was performed.

Before the recording, a mechanical frame with ultrasonic transducers and sonopads had been affixed on the human head in the intraventricular acoustic path position. An electrocardiographic 3-lead channel was used for the synchronization of each IBV pulse wave recording. Pulse waves which were distorted by artefacts were automatically excluded from further waveform analysis by the software of the pulse wave monitor.

Arterial blood pressure was measured in upright and supine positions. More than 3000 IBV pulse waves were analysed to show the differences of the IBV pulse wave shape and amplitude in supine and upright positions.

\section{Results of the Study}

The differences of the averaged IBV pulse wave shape and its amplitude for the group of 13 healthy volunteers in supine and upright body positions are shown in Fig. 4(a) and Fig. 4(b). Arterial blood pressure was measured in the group of healthy volunteers in both body positions.

It was $119 \pm 9 \mathrm{mmHg}$ and $74 \pm 7 \mathrm{mmHg}$ in the supine position and $122 \pm 10 \mathrm{mmHg}$ / $78 \pm 8 \mathrm{mmHg}$ in the upright position. 


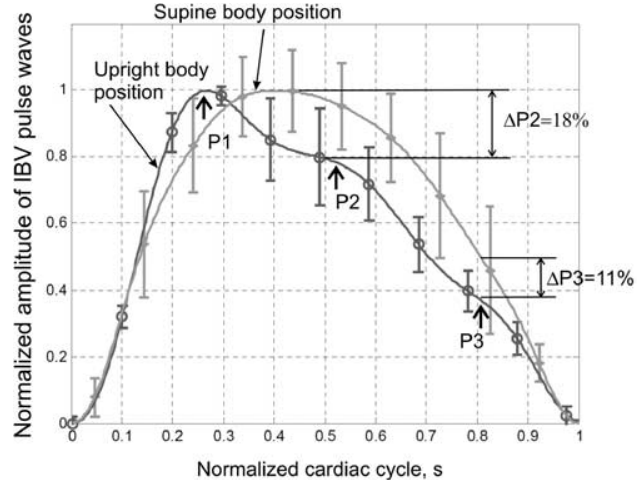

a)

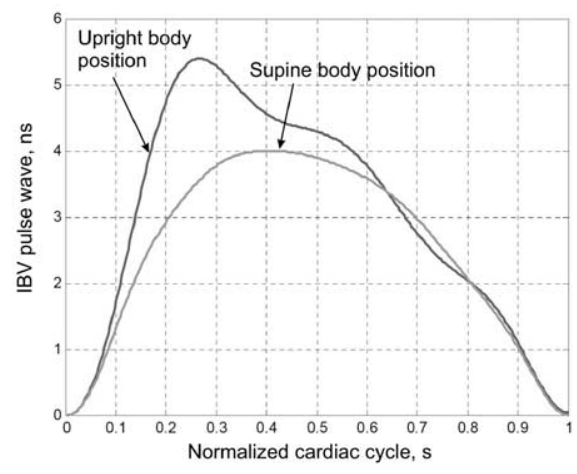

b)

Fig. 4. IBV pulse wave averaged shapes in the group of 13 healthy volunteers in upright and supine body positions: a) with marked subwaves $\mathrm{P} 1, \mathrm{P} 2$ and $\mathrm{P} 3$ and their differences, $\Delta \mathrm{P} 2=18 \%$ and $\Delta \mathrm{P} 3=$ $11 \%$, caused by body posture - vertical bars show physiological fluctuations of the pulse wave shape expressed as \pm SD for the entire group of healthy volunteers; $b$ ) non-normalised IBV pulse waves in upright and supine body postures.

The results show significant differences of IBV pulse wave shapes in the upright (highest intracraniospinal compliance) and supine (lower intracraniospinal compliance) body positions. Body posture caused changes in the IBV pulse waves, subwaves P2 and $\mathrm{P} 3$, by appropriate deviations $\Delta \mathrm{P} 2=\mathrm{P} 1-\mathrm{P} 2=18 \%$ and $\Delta \mathrm{P} 3=\mathrm{P} 1-\mathrm{P} 3=11 \%$ for the group of healthy volunteers (Fig. 4(a)). The differences are statistically significant with a $p$ value of 0.00001 or less.

The amplitude of the IBV pulse wave shape in an upright body position was significantly higher than it was in the supine body position (the averaged value of the amplitude's ratio was $1.55 \pm 0.61$ ). Such differences in IBV pulse wave shapes (Fig. 4(a)) and amplitudes (Fig. 4(b)) can be explained by physiological changes of arterial/venous blood and CSF volumetric waves in the different body positions. In previous studies, it has been discovered that the total venous outflow in an upright position is lower than it is, in comparison, with a supine position (Alperin et al., 2005). Slightly lower total cerebral blood flow and a lower CSF volume were found in the sitting position (Alperin et al., 2005).

The results of breathing holding test are shown in Fig. 5 .

Fig. 5 illustrates the possibility to obtain diagnostic information about the reactivity of parenchymal cerebral blood volume. The use of a non-invasive method makes it feasible to study cerebrovascular autoregulation in brain injured patients and to compare the results with data collected using identical methodology in normal control subjects.

\section{Advanced Pulse Wave Data Processing Using Wigner-Ville Distribution}

A time - frequency mapping for detection of otoacoustic emissions using Hilbert-Huang transform has been investigated by Janusauskas et al. (2006). New algorithm of automatic recognition of ischemic stroke area has been presented by Grigaitis et al. (2007). 


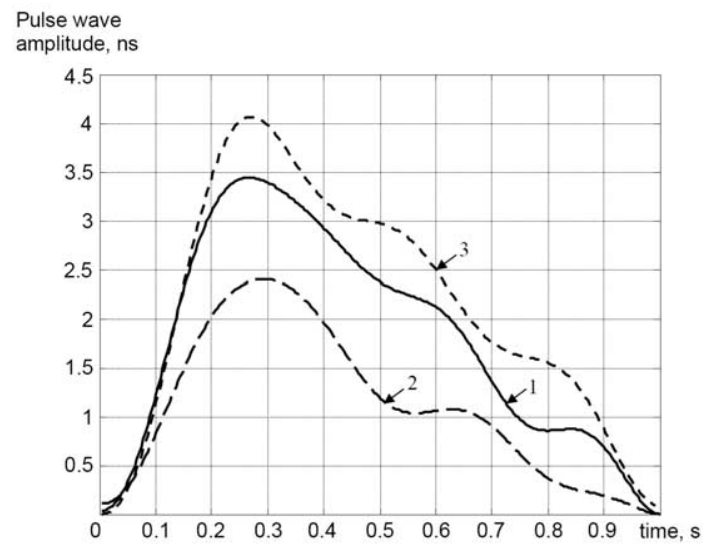

Fig. 5. Pulse wave dynamic (healthy volunteer GN) during the breath holding test (in the time domain): 1) wave data 2 min before the breath holding test (amplitude $3.4 \mathrm{~ns}$ ); 2) wave data for $20 \mathrm{sec}$ during the breath holding test (amplitude $2.4 \mathrm{~ns}$ ); 3) wave data $1 \mathrm{~min}$ after the breath holding test (amplitude $4.0 \mathrm{~ns})$.

To acquire information about pulse wave energy distributions in the frequency and time domain simultaneously, it is necessary to use the specific time-frequency representation form, which is suitable for extracting the necessary information from each individual signal. The dynamic of the pulse wave shape during the breath holding test is presented in Fig. 6.

Wigner-Ville distribution is a quadratic transform with attractive features for the multi-frequency biological signal analysis - time-frequency constant resolution and high energy concentration. Wigner-Ville $(W V)$ distribution associates with any signal $f(t)$ of

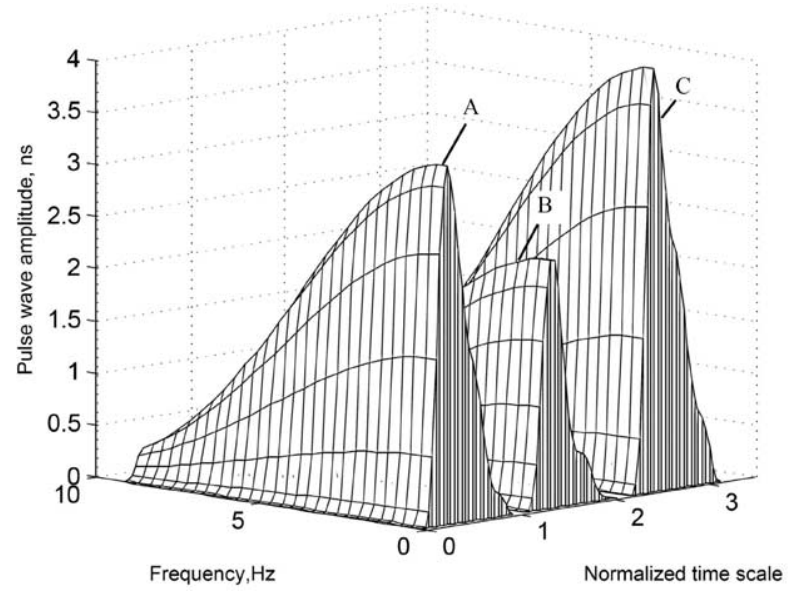

Fig. 6. Time-frequency representation of the pulse-wave dynamic (healthy volunteer GN) during the breath holding test (using the Wigner-Ville distribution): A) wave data 2 min before the breath holding test; B) wave data for $20 \mathrm{sec}$ during the breath holding test; C) wave data $1 \mathrm{~min}$ after the breath holding test. 
finished energy. This function depends on a time variable $(t)$ and the frequency $(\varpi)$ of the rectangularly shaped window signal $x(t)$ defined by (Latif et al., 1999):

$$
W V(t, \omega)=\int_{-\infty}^{+\infty} x\left(t+\frac{\tau}{2}\right) x^{*}\left(t-\frac{\tau}{2}\right) \exp (-i \tau \omega) \mathrm{d} \tau
$$

where $W V$ is Wigner-Ville distribution, *indicates a conjugate operation, $\tau$ is a length of the rectangularly shaped window. As a result, the Wigner-Ville distribution is a measure of the signal's local time-frequency energy.

The Wigner-Ville distribution of a multi-component ultrasonic signal possesses some "ghost patterns" corresponding to the interference between inner components. To reduce the native negative effect of the transform such as interference terms, the Smoothed Pseudo Wigner-Ville distribution $(S P W V)$ should be used. Such distribution attenuates the crossterms and enables a meaningful representation of the informal signal components like dominant frequencies. Unfortunately it reduces the time resolution. The $S P W V$ in a discrete form is given by Rodriguez et al. (2004) and Latif et al. (2006):

$$
\begin{aligned}
& S P W V(m \Delta t, k \Delta \omega) \\
& \quad=2 \Delta t \sum_{n=0}^{2 N-1} x[(m+n) \Delta t] x^{*}[(m-n) \Delta t] \cdot \exp (-i 2 \pi n k / 2 N),
\end{aligned}
$$

where $S P W V$ is Smoothed Pseudo Wigner-Ville distribution, $\Delta t$ is the time sampling interval, and $\Delta \varpi$ is a step of the frequency: $\Delta \varpi=\pi /(2 N \Delta t), m$ and $n$ denote margins of appropriate rectangularly shaped windows in time domain (in samples), $N$ is a total number of the signal samples in time domain, $k$ is a length of the frequency spectra region (in frequency samples) in which signal is being analysed, *indicates a conjugate operation.

Such a distribution, compared with an ordinary spectrum analysis, provides more information since it shows the evolution of the aspects of resonances and their amplitudes as a function of time (Rodriguez et al., 2004 and Latif et al., 2006).

The process of dominant frequencies detection (which are covered by artefacts and noise) in the pulse wave is based on the differences that exist between the time-frequency shape of the pulse wave and the noise or artefacts. The dynamic of the pulse wave shape during the breath holding test is presented in the time-frequency domain using the Wigner-Ville distribution (Fig. 6).

\section{Conclusions}

The effect of posture on intracraniospinal physiology can be quantified by the ultrasonic Vittamed intracranial blood volume pulse wave measurement method. It was shown that ultrasonically measured intracranial blood volume pulse wave shape and amplitude depend on changes in body posture and intracraniospinal compliance. Ultrasonically measured, posture-related changes of the intracranial blood volume pulse wave shape reflect intracraniospinal hydrodynamics and cerebral hemodynamics. 


\section{References}

Alperin, N. et al. (2005). Quantifying the effect of posture on intracranial physiology in humans by MRI flow studies. J. Magn. Reson. Imaging, 22, 591-596.

Chambers, I.R., G. Daubaris, E. Jarzemskas, K. Fountas, R. Kvascevicius, A. Ragauskas, S. Rocka, J.S. Robinson and A. Sitkauskas (2005). The clinical application of non-invasive intracranial blood volume pulse wave monitoring. Physiological Measurements, 26(6), 1019-1032.

Deltuva, V. (1999). Intracranial pressure measuring by using non-invasive sonographic technology. Doctoral Thesis of Biomedical Sciences, Hospital of Kaunas University of Medicine.

Fountas, K.N., A. Sitkauskas, C.H. Feltes, E.Z. Kapsalaki, V.G. Dimopoulos, M. Kassam, A.A. Grigorian, J.S. Robinson and A. Ragauskas (2005). Is non-invasive monitoring of intracranial pressure waveform analysis possible? Preliminary results of a comparative study of non-invasive vs. invasive intracranial slow-wave waveform analysis monitoring in patients with traumatic brain injury. Med. Sci. Monit., 11(2), 58-63.

Grigaitis, D., V. Bartkute and L. Sakalauskas (2007). An optimization of system for automatic recognition of ischemic stroke areas in computed tomogrphy images. Informatica, 18(4), 603-614.

He, P. (1998). Simulation of ultrasound pulse propagation in lossy media obeying a frequency power law. IEEE Ultrason. Ferroelec. Freq. Contr., 45, 114-125.

Hill, C.R. (1986). Physical Principles of Medical Ultrasonics. Ellis Horwood Limited.

Hynynen, K., and J. Sun (1999). Trans-skull ultrasound therapy: The feasibility of using image-derived skull thickness information to correct the phase distortion. IEEE Ulltrason. Ferroelec. Freq. Cont., 46, 752-755.

Janusauskas, A., V. Marozas, A. Lukosevicius and L. Sornmo (2006). The Hilbert-Huang transform for detection of otoacoustic emissions and time-frequency mapping. Informatica, 17(1), 25-38.

Kalasauskas, L. (2003). Diagnosis and treatment of traumatic subdural hygromas, possibility of using the new non-invasive ultrasonographic method. Doctoral Thesis of Biomedical Sciences, Hospital of Kaunas University of Medicine.

Kvascevicius, R. (2003). Transintracranial ultrasonic diagnostics in hydrocephalus. Doctoral Thesis of Biomedical Sciences, Vilnius University Emergency Hospital.

Latif, R., E.H. Aassif, G. Maze, A. Moudden and B. Faiz. (1999). Determination of the group and phase velocities from time-frequency representation of Wigner-Ville. NDT\&E International, 32, 415-422.

Latif, R., H. Aasif, A. Moudden, B. Faiz and G. Maze. (2006) The experimental signal of a multilayer structure analysis by the time-frequency and spectral methods. NDT \& International, 39, 349-355.

Matukevicius, A. (2000). Testing of intracranial medium volume dynamics by using new sonographic technology. Doctoral Thesis of Biomedical Sciences, Hospital of Kaunas University of Medicine.

Ragaisis, V. (2003). Non-invasive optimised monitoring of cerebrovascular autoregulation in patients after severe head injury. Doctoral Thesis of Biomedical Sciences, Hospital of Kaunas University of Medicine.

Ragauskas, A., and G. Daubaris (1995). US Patents 5,388,583, 1995, 6,387,051, 2002.

Ragauskas A., G. Daubaris, V. Ragaisis and V. Petkus (2003). Implementation of non-invasive brain physiological monitoring concepts. Medical Engineering and Physics, 25, 667-678.

Ragauskas, A. et al. (1999-2004). Cerebrovasc Dis 1999; 9 (suppl. 2):31, 46; 2000; 10 (suppl. 1):34; 2001; 11 (suppl. 3): 44; 2002; 13 (suppl. 4, 25); 2003; 16 (suppl. 4):18, 2004; 17 (suppl. 4): 04.

Ragauskas, A., and A. Kanapienis (1999). Simultaneous invasive and non-invasive ICP waves study on animals. Medical \& Biological Engineering \& Computing, 37(1), 330-331.

Ragauskas, A., V. Petkus and R. Jurkonis (1999). Simulation of ultrasound pulse propagation through human cranium. J. IFMBE Medical \& Biolog. Engineering \& Computing, 37(S1), 426-427.

Ragauskas, A., V. Petkus and R. Jurkonis (2002). Investigation of intracranial media ultrasonic monitoring model. Ultrasonics, 40, 827-831.

Raksin, P.B., N. Alperin et al. (2003). Non-invasive intracranial compliance and pressure based on dynamic MRI of blood flow and CSF flow. Neurosurg Focus, 14(4), article 4.

Rocka, S. (2003). Hydrodynamic peculiarities of the non-invasively acquired ultrasonic intracranial pulse waves. Doctoral Thesis of Biomedical Sciences, Vilnius University Emergency Hospital.

Rodriguez, M.A., J.L. San Emeterio, J.C. Lazaro and A. Ramos (2004). Ultrasonic flaw detection in NDE of highly scattering materials using wavelet and Wigner-Ville transform processing. Ultrasonic, 42, 847-851.

Szabo, T.L. (1995). Causal theories and data for acoustic attenuation obeying frequency power law. J. Acoust. Soc. Am., 97, 14-24. 
A. Ragauskas is a full university professor of Kaunas University of Technology since 1992, head of Telematics Scientific Laboratory of Kaunas University of Technology since 1993, member of Steering Group of International Research Group "Brain - Information Technologies (BrainIT)", and director of Development and Research of Vittamed Technologijos (VT).

G. Daubaris is a senior research associate of Kaunas University of Technology since 1989, senior research associate of Telematics Scientific Laboratory since 1993, researcher of VT.

V. Petkus is a senior research associate of Telematics Scientific Laboratory since 2000, and researcher of VT.

R. Chomskis is a research associate of Telematics Scientific Laboratory of Kaunas since 1995, and engineer researcher of VT.

R. Raisutis is a research associate of Ultrasound Institute of Kaunas University of Technology since 2005, and engineer researcher of VT.

V. Deksnys is a professor associate of Kaunas University of Technology, and engineer researcher of VT.

J. Guzaitis is a doctoral student of Kaunas University of Technology since 2004, and engineer researcher of VT.

G. Lengvinas is a doctoral student of Kaunas University of Technology since 2004, and Engineer Research of VT.

V. Matijosaitis is a doctoral student of Kaunas University of Medicine since 2007, and engineer researcher of VT.

\section{Neinvazinė intrakranijiniu pulsinių bangu stebėsena}

Arminas RAGAUSKAS, Gediminas DAUBARIS, Vytautas PETKUS, Romanas CHOMSKIS, Renaldas RAISUTIS, Vytautas DEKSNYS, Jonas GUZAITIS, Gintautas LENGVINAS, Vaidas MATIJOSAITIS

Neinvaziniai fiziologinès būsenos monitoriai yra svarbi intensyvios terapijos sistemų dalis. Šiame darbe pasiūlyti inovatyvūs informaciniai metodai ir technologija skirta neinvazinei žmogaus smegenų tūrinių pulsinių bangụ fiziologinei stebėsenai. Naujos neinvazinès ultragarsinės intrakranijinių pulsinių bangų stebèsenos technologijos eksperimentinė studija parodè neinvaziniu būdu užregistruotų intrakranijinių kraujo tūrinių pulsinių bangų formų reakcijas esant skirtingoms žmogaus kūno padètims. Buvo ištirta 13 sveiku savanoriu grupè. Esant skirtingoms žmogaus kūno padetims, buvo gauti kraujo tūriniu pulsiniu bangu formu pokyčiai charakteringuose taškuose: $\Delta \mathrm{P} 2=18 \%$ ir $\Delta \mathrm{P} 3=11 \%$. Vertikalioje ir horizontalioje žmogaus kūno padètyse buvo gauti tokie kraujo tūrinių pulsinių bangų amplitudžių santykiai $1.55+/-0.61$. 